\title{
REHABILITASI PENYALAHGUNAAN NARKOBA UNTUK REMAJA DI BANJARBARU
}

\author{
Dhea Aghnia Putri Machfuyana \\ Program Studi Teknik Arsitektur Fakultas Teknik Universitas Lambung Mangkurat \\ dheamachfuyana07@gmail.com \\ Dila Nadya Andini \\ Program Studi Teknik Arsitektur Fakultas Teknik Universitas Lambung Mangkurat \\ dila.andini@ulm.ac.id
}

\begin{abstract}
ABSTRAK
Rehabilitasi Sosial Penyalahgunaan Narkoba Untuk Remaja Di Banjarbaru adalah suatu lembaga yang bertugas untuk merawat dan menjaga pasien remaja yang menyalahgunakan narkoba agar pulih dari ketergantungannya. Perancangan Rehabilitasi Sosial ini dikarenakan banyaknya remaja yang menggunakan narkoba dan belum adanya fasilitas rehabilitasi khusus untuk remaja. Permasalahan yang diangkat dari laporan ini adalah bagaimana mewujudkan desain rehabilitasi sosial dengan ruang luar dan ruang dalam yang dapat membantu proses penyembuhan. Metode yang digunakan untuk memecahkan permasalahan yang ada adalah dengan menggunakan healing environment. Dari data tersebut maka muncullah konsep healing environment untuk mewujudkan desain ruang luar dan ruang dalam yang dapat membantu dalam penyembuhan.
\end{abstract}

Kata kunci: Rehabilitasi Sosial Penyalahgunaan Narkoba, Remaja, Healing Environment

\begin{abstract}
Social Rehabilitation of narcotics abuse for adolescents In Banjarbaru is an institution which takes care and maintains adolescents patients who abuse narcotics to recover from their addiction. Social Rehabilitation Design is due to the large number of adolescents who use drugs and there are no special rehabilitation facilities for them yet. Issues raised in this report is how to create the design of social rehabilitation with outer space and inner space that can help the healing process. The method used to solve the issues using a healing environment. From these data, the healing environment concept emerged to create the design of outer space and inner space that can help in healing.
\end{abstract}

Keywords: Social Rehabilitation of Narcotics Abuse, Adolescent, Healing Environment

\section{PENDAHULUAN}

Kota Banjarbaru adalah salah satu kota di provinsi Kalimantan Selatan, Indonesia. Sebanyak 55.598 jiwa di Kalimantan Selatan menggunakan narkoba, Kalimantan sendiri menduduki posisi peringkat 5 dari 34 provinsi dikutip dari Media Indonesia, 29 Juli 2018). Di Kalimantan Selatan rehabilitasi medis penyalahgunaan narkoba sendiri hanya ada di RSJ Sambang Lihum dan sudah dibilang cukup baik sedangkan untuk rehabilitasi non medis nya sudah ada namun dapat dibilang belum cukup baik dan bukan tempat yang khusus untuk merehabilitasi remaja penyalahguna narkoba saja.

Untuk rehabilitasi non-medis di Kalimantan Selatan sendiri terdapat lembaga swadaya masyarakat dan panti rehabilitasi keagamaan seperti pondok Inabah. Metode penyembuhan di pondok inabah ini adalah menggunakan kajian Living Al-Qur'an, yang mana para pasien dibimbing dan diobati dengan cara islami atau berpedoman pada 
Al-Qur'an. Kegiatan yang dilakukan adalah seperti sholat 5 waktu berjamaah, dzikir, tadarus Al-Qur'an, ceramah agama, mandi taubat dan mandi bungas, dan lain-lain. Pondok inabah sekarang hanya menjalankan proses perawatan rawat jalan saja karena fasilitas untuk rawat inapnya rusak dikarenakan rubuh dan hanya tertinggal bangunan tunggal seperti gambar no 1 berikut. Pasien yang mengikuti pengobatan di pondok inabah ini kebanyakan para remaja lelaki, meskipun pasiennya kebanyakan para remaja pondok inabah ini masih bersifat umum tidak khusus untuk remaja saja. Pondok inabah sendiri memfokuskan perawatan di rehabilitasi sosialnya. Meskipun dengan adanya tempat rehabilitasi yang ada bangunan tersebut bersifat umum tidak ditujukan hanya untuk para remaja dan fasilitasnya sendiri kurang layak dan tidak lengkap.

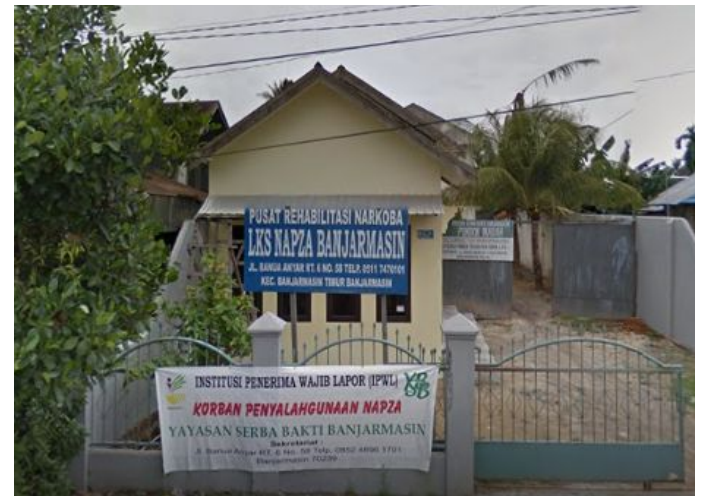

Gambar 22. Pondok Inabah

Dan tercatat pengkonsumsi aktif narkoba di banjarbaru kisaran usia 15-19 tahun yang mana masih berstatus pelajar dan mahasiswa Rehabilitasi sosial untuk remaja ini dilandasi oleh undang-undang no. 35 pasal 59 tahun 2014 tentang perlindungan anak, yang mana ada 15 kategori anak yang memerlukan perlindungan dan perhatian khusus. Salah satunya adalah anak yang menjadi korban penyalahgunaan narkotika, alkohol, psikotropika, dan zat adiktif. Oleh karena itu, proses rehabilitasi remaja harus dipisahkan dari orang dewasa karena pasien remaja ini memerlukan perlindungan dan perhatian khusus. Karena kebanyakan remaja yang menggunakan narkoba mengalami dampak yang sangat besar seperti dikeluarkan dari sekolah, kesempatan untuk melanjutkan pendidikan dan bekerja susah, dikucilkan dan menjadi anti sosial, tidak dipercayai lagi, dapat tertular penyakit HIV dan AIDS, dan dapat menjadi pelaku kriminal. Oleh karena itu, perlu tempat rehabilitasi narkoba untuk para remaja yang diwujudkan dengan lingkungan yang mendukung seperti aman, nyaman, tidak mengekang, dapat memulihkan ketergantungan dari narkoba dan dapat berkegiatan normal lagi di lingkungan sekitarnya.

\section{PERMASALAHAN}

Berdasarkan pemikiran di atas, maka untuk penyelesaian desain Rehabilitasi Sosial Penyalahgunaan Narkoba Untuk Remaja di Banjarbaru adalah dengan merancang rehabilitasi sosial yang dapat memenuhi kebutuhan aktivitas penyembuhan remaja ketergantungan narkoba dengan menerapkan lingkungan yang dapat menyembuhkan (healing environment).

\section{TINJAUAN PUSTAKA}

\section{A. Tinjauan Umum Rehabilitasi}

Rehabilitasi merupakan lembaga pelayanan sosial yang dibina oleh pemerintah atau swasta. Adapun rehabilitasi narkoba diharapkan dapat menyembuhkan seseorang dari ketergantungan mengkonsumsi narkoba, dengan kegiatan berupa memberikan skill keterampilan, memberikan edukasi, dan terapi.

Rehabilitasi sendiri dibagi menjadi 3 tahap, yaitu: rehabilitasi medis, rehabilitasi sosial, dan pasca rehabilitasi.

Rehabilitasi medis bertujuan menghilangkan dan membersihkan tubuh dari zat-zat narkoba.

Adapun rehabilitasi sosial ini adalah wujud perlindungan sosial terhadap korban supaya dapat mengikuti tatanan sosial dan hukum agar tidak mengulangi kesalahan yang sama. Kegiatan rehabilitasi sosial berupa penyembuhan fisik, psikis, dan sosial, contohnya seperti terapi jasmani, terapi psikiatri, terapi psikososial, terapi psikoreligius, dan edukasi informasi. Hal tersebut bertujuan agar pengguna dapat kembali berkegiatan dan berguna di lingkungan sosialnya. 


\section{B. Tinjauan Narkoba}

Narkoba berasal dari kata narkotika dan obat berbahaya. Atau juga dapat dikenal dengan sebutan napza (narkotika, psikotropika, dan zat adiktif). Zat terlarang ini dapat digunakan dengan cara dimakan, minum, hirup, dan disuntikkan. Zat terlarang ini dapat mengubah susunan saraf inti dan metabolisme rusak, dapat mempengaruhi psikologi seseorang (perubahan perilaku, pikiran, suasana hati, dan perasaan seseorang), juga dapat menurunkan kualitas diri.

\section{Tinjauan Remaja}

Remaja merupakan sebuah fase dimana setiap manusia yang menuju dewasa mengalaminya. pada masa remaja mengalami perubahan pada fisik dan cara berfikir. Rentang umur seseorang dikatakan remaja adalah berawal dari usia 11-21 tahun.

Sifat dan tingkah seorang remaja yang menggunakan narkoba adalah memiliki emosi yang meledak-ledak atau belum stabil, tidak dapat diatur yang mana dapat melakukan perbuatan yang melanggar norma-norma yang berlaku, kata-katanya tidak dapat dipercaya, menarik diri dari lingkungan, dan prestasi pada bidang akademik maupun non-akademik mulai menurun. Faktor-faktor remaja menggunakan narkoba adalah memiliki rasa keingintahuan yang tinggi, dirayu oleh tmean atau orang lain karena apabila tidak menggunakan tidak dianggap teman, kemudian maslaah keluarga juga dapat menjadi faktor. Pada rehabilitasi sosial seorang remaja yang dirawat berada pada tahap awal dan menengah tingkat penggunaan narkoba.

\section{Tinjauan Peran Healing Environment}

Psda tahap proses penyembuhan faktor lingkungan sangatlah berperan penting. Karena $40 \%$ faktor lingkungan, $10 \%$ faktor medis, $20 \%$ faktor genesis, dan $30 \%$ faktor lainnya menurut Ken Jones dalam Health and Human Behaviour 2003. Dalam merancang bangunan yang berkonsep Healing Environment dilakukan dalam 3 pendekatan, yaitu Alam, panca indra, dan psikologis. Ketiga faktor tersebut saling berhubungan dan dapat mempengaruhi lingkungan terapi yang di desain. tersebut.

Berikut penjelasan ketiga faktor

\section{Pendekatan Alam}

Pendekatan alam untuk penyembuhan memberikan dampak yang besar hal ini dikarenakan dapat menurunkan stress yang tinggi dan dapat membuat keadaan emosi menjadi stabil, adapun penerapan pada arsitektur adalah dengan mengolah taman pada kawasan ataupun di dalam bangunan.

\section{Pendekatan Indra}

Pada proses penyembuhan juga dapat mengandalkan panca indra, seperti penglihatan, pendengaran, penciuman, dan perasa. Hal ini diterapkan pada arsitektur berupa:

\section{a. Indra penglihatan}
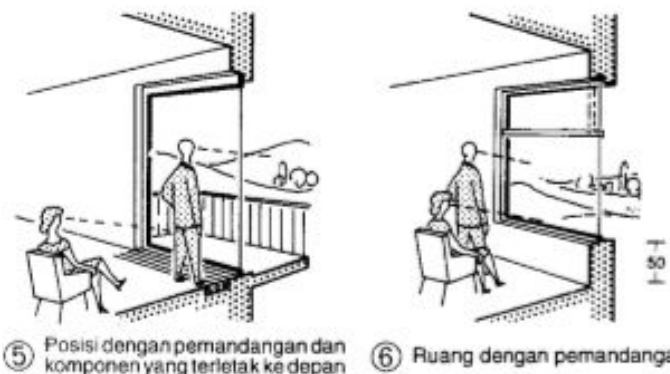

(6) Auang dengan pernandangan

\section{Gambar 23. Ruangan yang menghadap langsung kearah taman}

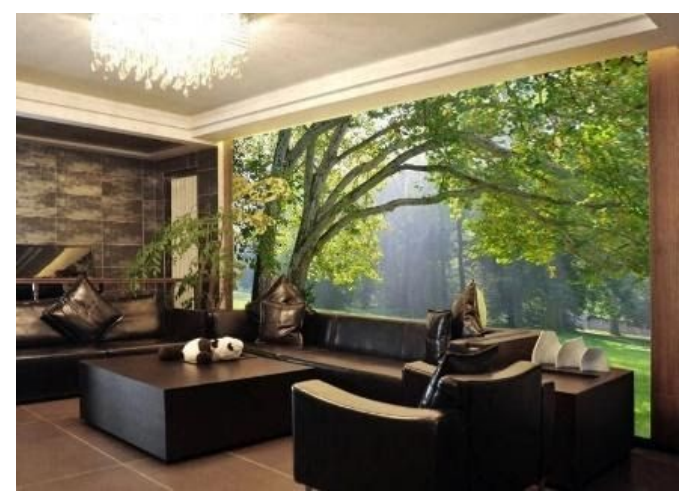

Gambar 24. Menggunakan lukisan pada interior, hal ini dapat menciptakan suasana tenang 

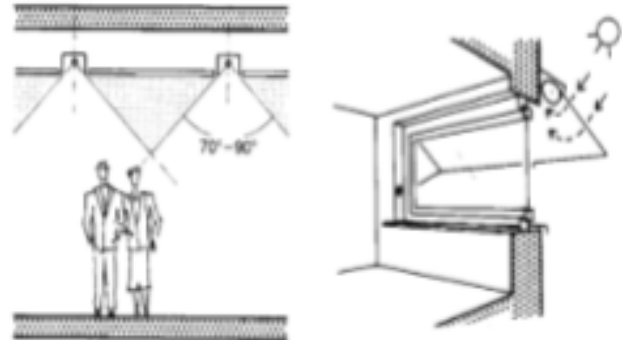

Gambar 25. Memasukkan cahaya alami ataupun buatan yang dapat membantu proses

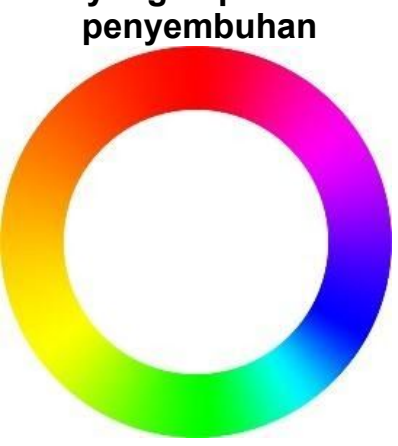

Gambar 26.Penggunaan warna dapat mempengaruhi penyembuhan pasien.

b. Indra Pendengaran

Dengan memasukkan suara yang menyenangkan dan menenangkan mampu mengurangi stress dan membuat suasana menjadi tenang dan rileks, contohnya adalah suara gemericik air.

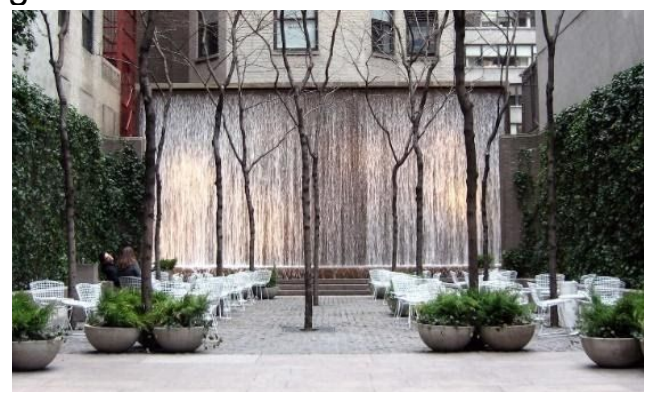

\section{Gambar 27. Suara gemericik air dapat menenangkan}

c. Indra Penciuman

Pada proses penyembuhan indra penciuman juga sangat membantu, dikarenakan menghirup aroma yang harum dapat meningkatkan ketenangan, meringankan stress, meringankan insomnia, dan dapat membuat lebih bahagia.

Hal ini dapat diterapkan pada pemilihan vegetasi yang dikira cocok, seperti berikut:

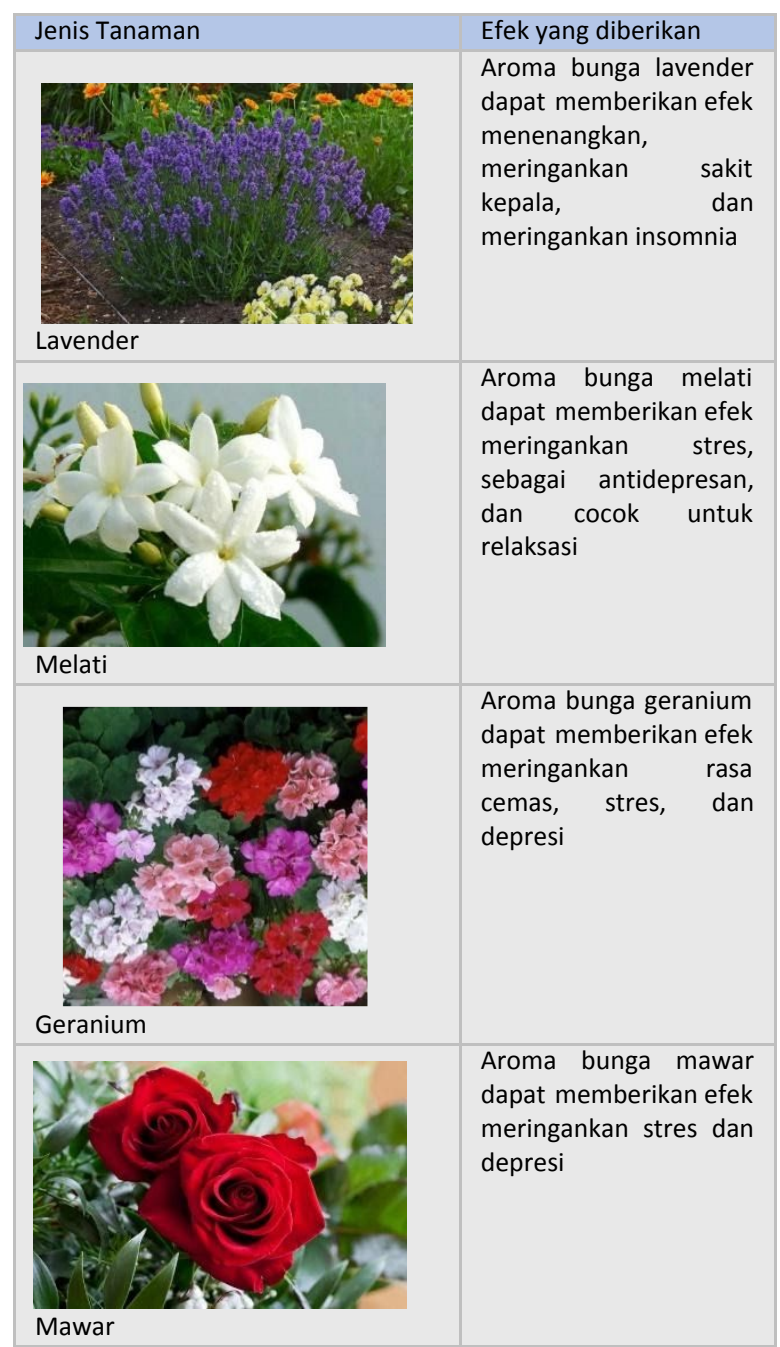

(Sumber: data hasil penulis)

\section{Pendekatan Psikologis}

Secara psikologis, healing environment sangat membantu dalam proses pemulihan pasien, karena untuk perawatan medis diterapkan kasih sayang, empati, komunikasi, kenyamanan, dukungan emosional, dan dukungan dari keluarga, teman, dan kerabat. Hal ini dapat diwujudkan ke dalam arsitektur dengan menyediakan fasilitas ruang komunal atau bersama. Misalnya seperti ruang konsultasi bersama, aula, ruang santai, dan lain-lain.

\section{METODE}

Metode yang digunakan untuk mempermudah dalam merumuskan dan menyelesaikan dalam perancangan Rehabilitasi Penyalahgunaan Narkoba Untuk Remaja Di Banjarbaru adalah healing environment. Healing environment dipilih karena dapat memecahkan masalah yang ada karena lingkungan yang sehat dapat 
memegang peranan penting dalam proses penyembuhan. Healing environment sendiri dilakukan dalam tiga pendekatan yaitu alam, panca indra, dan psikologis.

\section{PEMBAHASAN}

\section{A. Konsep Program}

Konsep perancangan Rehabilitasi Sosial Penyalahgunaan Narkoba Untuk Remaja Di Banjarbaru untuk memudahkan dalam merancang berdasarkan analisis yang ada dengan pendekatan healing environment dan dipadukan dengan permasalahan arsitektur. Maka diterapkan lah konsep healing environment sebagai pemecahan permasalahan tersebut.

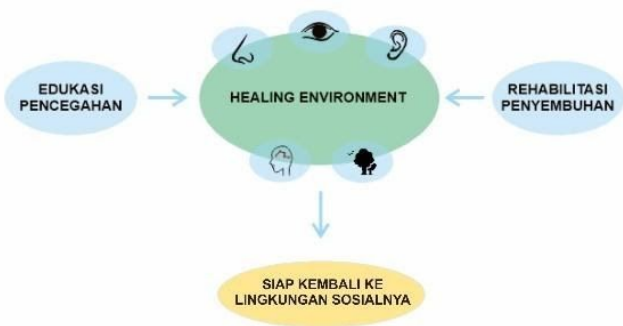

\section{Gambar 28. Konsep Programatik}

Tujuan dari menggunakan konsep healing environment dalam merancang adalah, agar para pasien maupun pengunjung dapat sembuh dan teredukasi akan bahayanya menggunakan narkoba.

\section{B. Penerapan Konsep Healing \\ Environment}

Konsep healing environment diterapkan pada ruang dalam dan ruang luar.

1. Healing Environment pada Interior

Pada bagian interior untuk kamar residen berfokus pada kenyamanan dengan menerapkan indra penglihatan, psikologi, dan unsur alam. Kamar menggunakan warna cat pada dinding yang dapat membuat rileks, penggunaan material yang aman, dan kamar menghadap ke arah taman.

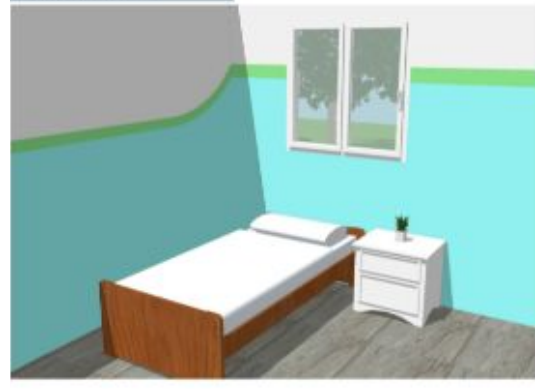

\section{Gambar 29. Konsep Interior pada Kamar Pasien}

Area bersama seperti ruang makan dibuat agar senyaman mungkin dengan menggunakan bukaan yang besar, bertujuan agar cahaya matahari dan penghawaan alami dapat masuk ke dalam. Pada bagian luar bangunan ditumbuhi dengan vegetasi yang memiliki aroma menenangkan.

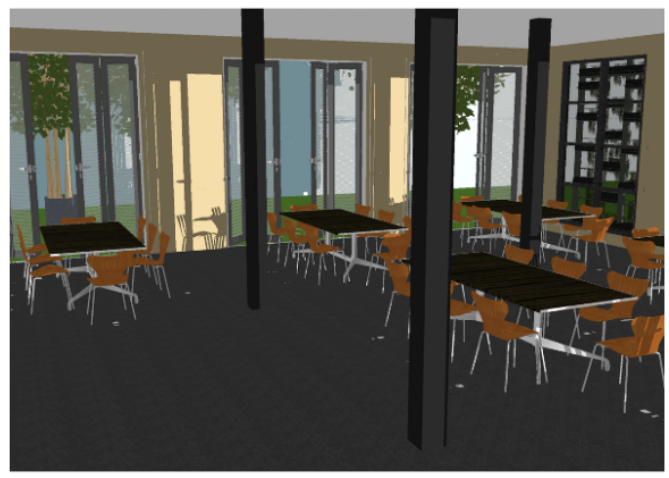

Gambar 30. Konsep Interior pada Ruang Makan

Pada ruang konsultasi individu dibuat agar senyaman mungkin agar para pasien yang berkonsultasi dapat menceritakan masalahnya dengan nyaman dan tanpa ada rasa beban. Ruangan dibuat menghadap ke arah taman agar pasien merasa relaks. Pada ruangan diterapkan beberapa aspek seperti indra penglihatan, unsur alam, dan psikologi.

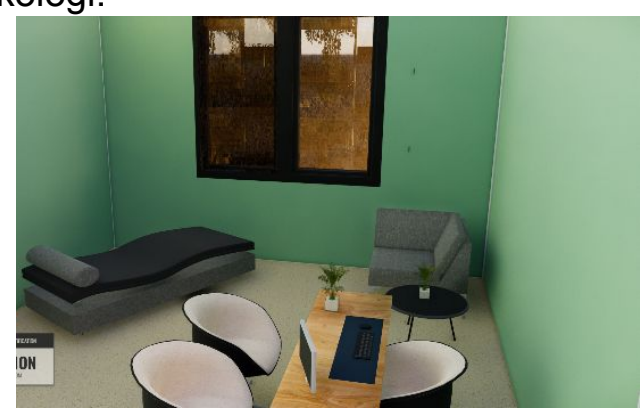

Gambar 31. Konsep Interior Pada Ruang Konsultasi Individu 
Pada bagian Lobby bangunan psikologis bagian dalam bangunan dicat dengan warna biru, hal ini diharapkan agar pasien dapat rileks.

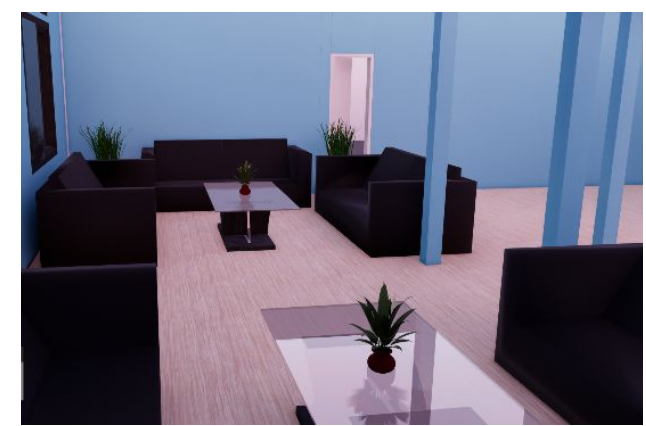

Gambar 32. Konsep Interior Pada Lobby Bangunan Psikologis

2. Healing Environment pada Eksterior

Pada ruang luar dimaksimalkan pada bagian taman. Penggunaan soft material dan hard material pada rencana tapak.

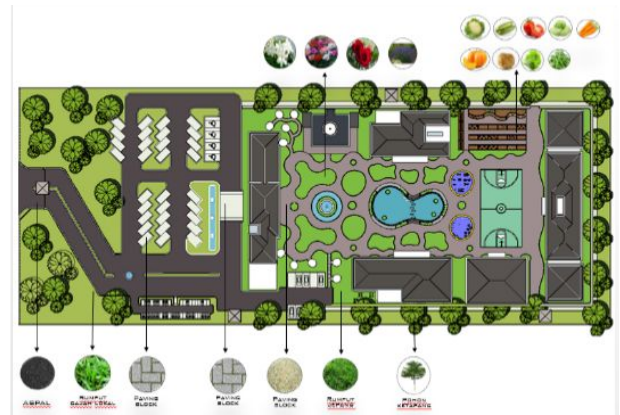

Gambar 33. Rencana Tapak

Diantara dua bangunan diletakkan taman dan kolam, hal ini para pasien merasa rileks dan tidak bosan.

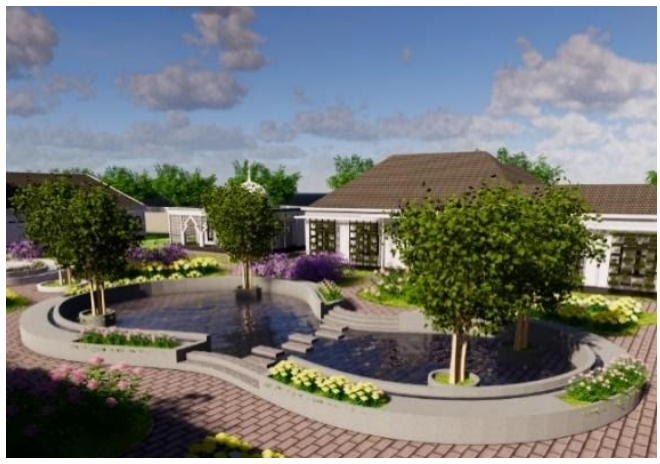

Gambar 34. Taman

Pada bagian area yang lain terdapat area berkebun. Hal ini diharapkan agar para pasien dapat melatih kesabaran dan proses penyembuhan.

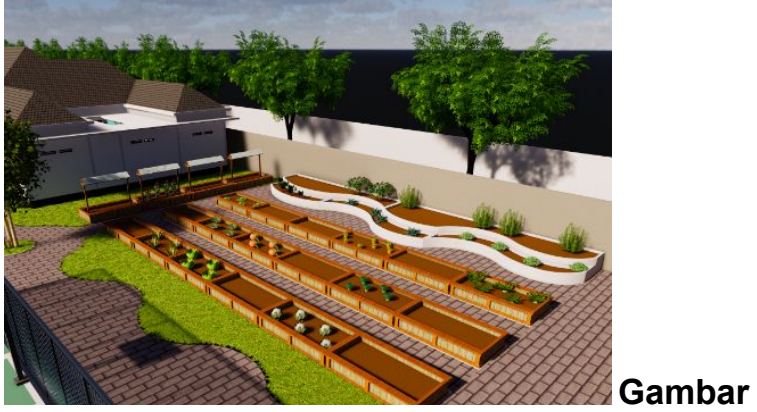

35. Area Berkebun

Dan pada bagian taman yang lain terdapat outdoor gym, hal ini agar para pasien dapat bugar dan sehat.

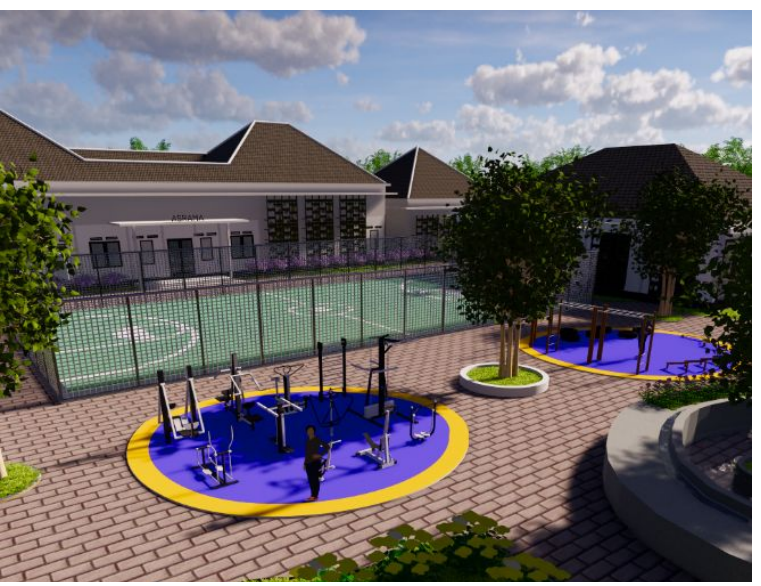

Gambar 36. Area Outdoor gym

\section{Penerapan Konsep Jaringan Air Bersih dan Air Kotor}

Distribusi air bersih bersumber dari PDAM yang akan ditampung pada reservoir utama atau primer pada kawasan yang akan didistribusikan ke reservoir sekunder untuk selanjutnya dialirkan ke bagian-bagian di dalam ruangan yang memerlukan air dan pada luar bangunan.
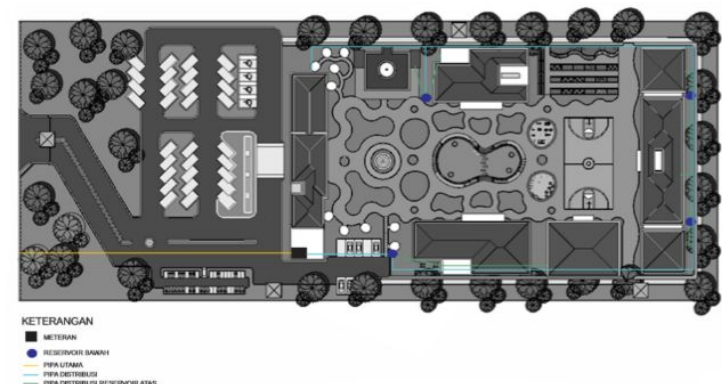

Gambar 37.Rencana distribusi air bersih pada kawasan 


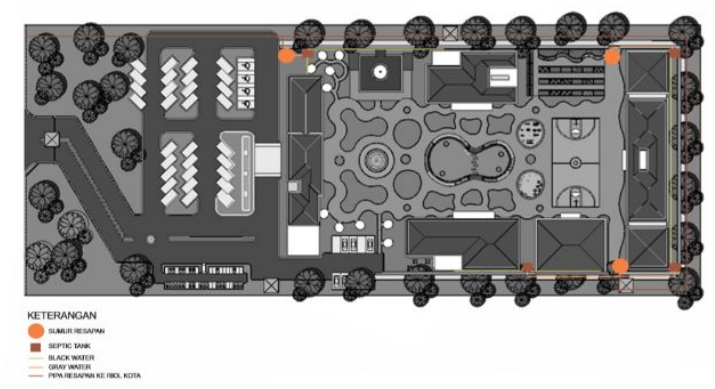

Gambar 38. Rencana distribusi air kotor pada kawasan

\section{Hasil Rancangan}

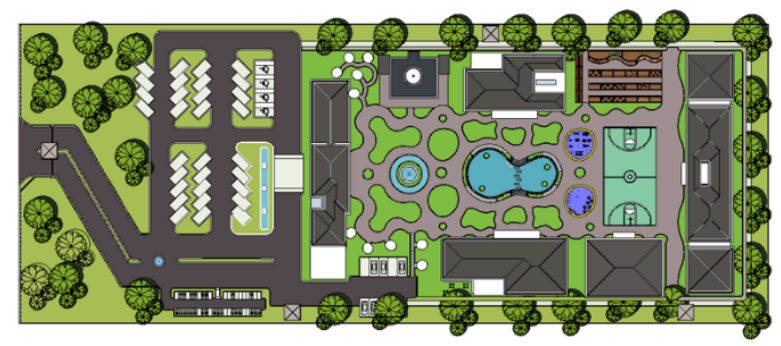

Gambar 39. Siteplan Rehabilitasi Sosial

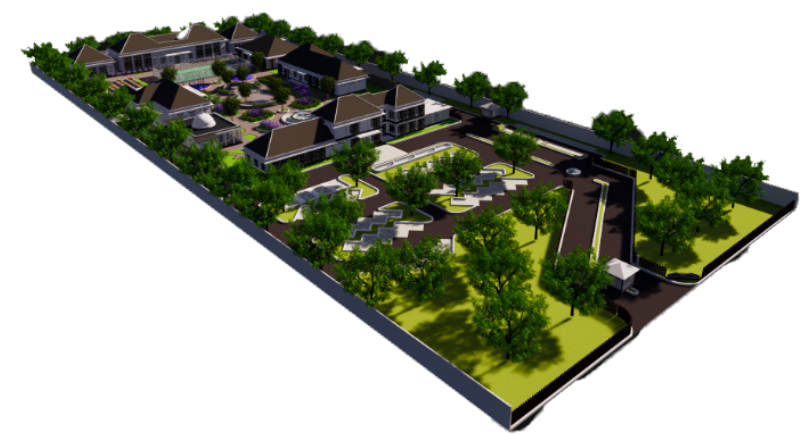

Gambar 40. Perspektif Rehabilitasi Sosial

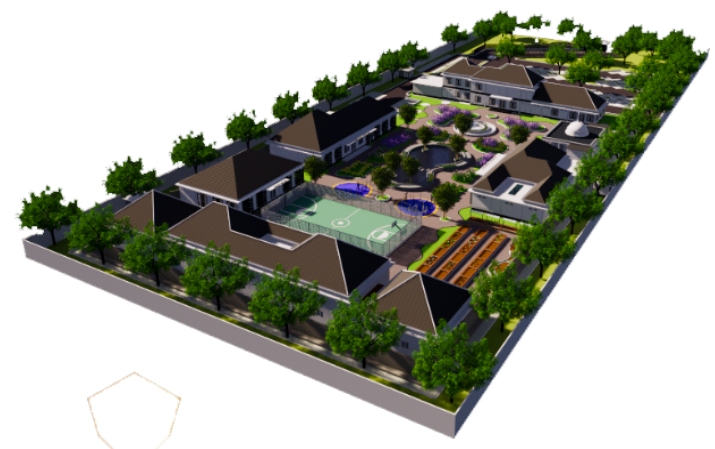

Gambar 41. Perspektif Rehabilitasi Sosial

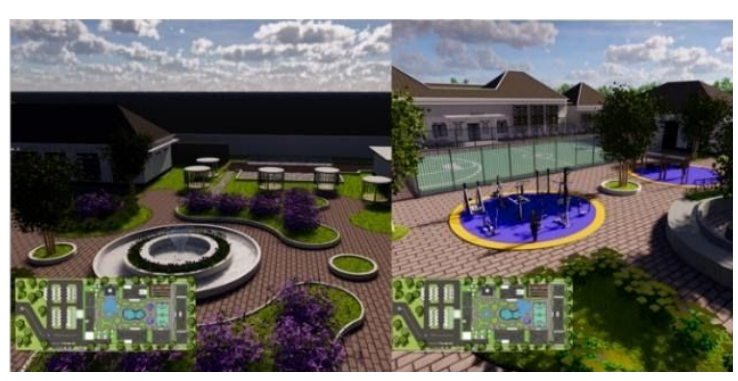

Gambar 42.Area taman dan Outdoor gym

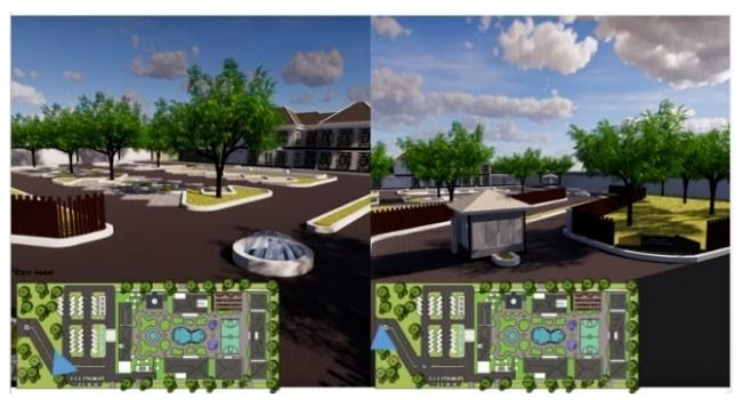

Gambar 43.Area Parkir dan area depan Gerbang

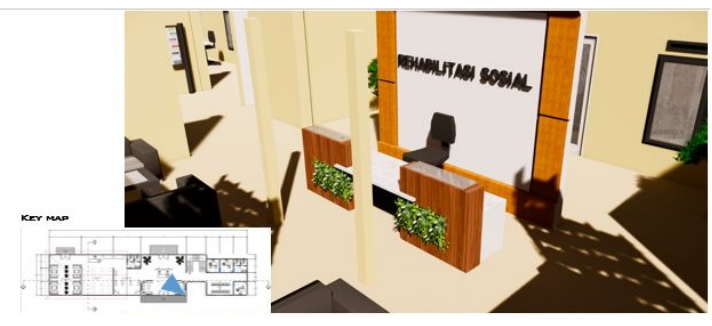

Gambar 44. Lobby Bangunan 1

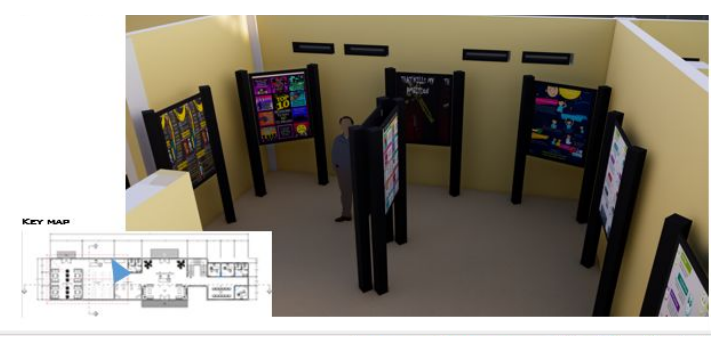

Gambar 45. Ruang Edukasi

\section{KESIMPULAN}

Rehabilitasi Sosial Penyalahgunaan Narkoba Untuk Remaja Di Banjarbaru diharapkan dapat menjadi suatu wadah yang dapat mengurangi angka pengguna narkoba dikalangan remaja dan agar para remaja dapat bersosialisasi dengan lingkungannya lagi dan mendapatkan pekerjaan dan pendidikan yang layak. Dengan menggunakan konsep healing environment, yang didasari dari faktor lingkungan memegang peranan besar dalam proses penyembuhan. Konsep ini dipilih karena 
paling cocok untuk rancangan Rehabilitasi Sosial Penyalahgunaan Narkoba Untuk Remaja ini. Konsep healing environment dicapai melalui bentukan tatanan massa yang dikelompokkan berdasarkan sifat dan hirarki dari fungsi bangunan, bentukan ruang dan sirkulasi, indra penglihatan (warna, cahaya, pemandangan alam), indra pendengaran (berupa suara gemericik air), indra penciuman (vegetasi dan aromaterapi), psikologis yang kemudian disesuaikan dengan kebutuhan dan aktivitas penggunanya yaitu remaja penyalahguna narkoba.

\section{DAFTAR PUSTAKA}

Anggraini, V. 2010. Pusat Rehabilitasi Narkoba Di Batu, Tema: Arsitektur Perilaku (Hirarki Human Needs) [Skripsi]. Malang: UIN Maulana Malik Ibrahim

Atmadjaja, JS, dan Dewi, MS. 1999. Estetika Bentuk. Bahan Ajar. Jakarta: Program S1 Arsitektur

BNNI. (2012). Buku Panduan Pencegahan Penyalahgunaan Narkoba Sejak dini

Ching, FD. 2000. Bentuk, Ruang, dan Tatanan. Jakarta: Erlangga

Darmaprawira, W.A. Sulasmi (2002) Warna: teori dan kreativitas penggunaannya ed. Ke-2. Bandung: Penerbit ITB

Djimantoro, MI, dan Demetrius, Y. 2014. Penggunaan Tanaman Hias Untuk
Meningkatkan Fasilitas Terapi Anak. Volume 5:79

Firdha R. 2016. Rehabilitasi Sosial Untuk Penyalahguna Napza Di Yayasan Karya Peduli Kita Tangerang Selatan [Skripsi]. Jakarta: UIN Syarif Hidayatullah

Fitriyani. A. (2013) Pusat Rehabilitasi Narkotika Kalimantan Barat

Hakim, Rustam, dan Utomo, Hardi. 2002. Komponen Perancangan Arsitektur Lansekap: Prinsip-Unsur dan Aplikasi Disain, Jakarta: Bumi Aksara

Haryanto. 2009. Rehabilitasi dan Pekerjaan Sosial. Bahan Ajar. Yogyakarta: Program S1 Pendidikan Luar Biasa

Hasudungan, J.A., Ernawaty, J., \& Santosa, H. Penerapan Konsep Healing Garden Pada Pusat Rehabilitasi Narkoba di Batu

Herlina. 2013. Bibliotherapy: Mengatasi Anak dan Remaja melalui Buku. Bandung: Pustaka Cendekia Utama

Neufert, E. (1996). Data Arsitek Jilid 1. Jakarta: Eirlangga

Saraswati. T. (2003). Pengaruh Tata Ruang Bangsal Rumah Sakit

Undang-Undang Dasar 1945

Venardo. R. Indahnya Hidup Tanpa Narkoba 